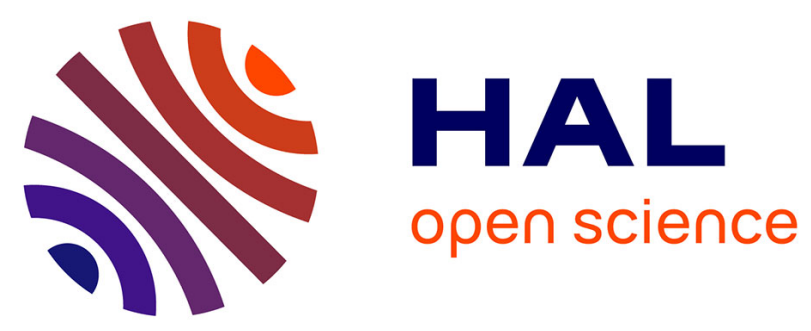

\title{
VISCOSITY OF NEMATIC-CHIRAL MIXTURES AND THEIR ELECTROOPTICAL CHARACTERISTICS
}

Z. Elashvili, M. Mkhatvrishvili, T. Piliashvili, G. Chilaya, K. Japaridze

\section{- To cite this version:}

Z. Elashvili, M. Mkhatvrishvili, T. Piliashvili, G. Chilaya, K. Japaridze. VISCOSITY OF NEMATIC-CHIRAL MIXTURES AND THEIR ELECTROOPTICAL CHARACTERISTICS. Journal de Physique Colloques, 1979, 40 (C3), pp.C3-22-C3-24. 10.1051/jphyscol:1979306 . jpa-00218696

\section{HAL Id: jpa-00218696 https://hal.science/jpa-00218696}

Submitted on 1 Jan 1979

HAL is a multi-disciplinary open access archive for the deposit and dissemination of scientific research documents, whether they are published or not. The documents may come from teaching and research institutions in France or abroad, or from public or private research centers.
L'archive ouverte pluridisciplinaire HAL, est destinée au dépôt et à la diffusion de documents scientifiques de niveau recherche, publiés ou non, émanant des établissements d'enseignement et de recherche français ou étrangers, des laboratoires publics ou privés. 


\title{
VISCOSITY OF NEMATIC-CHIRAL MIXTURES AND THEIR ELECTROOPTICAL CHARACTERISTICS
}

\author{
Z. M. ELASHVILI, M. D. MKHATVRISHVILI, T. S. PILIASHVILI, \\ G. S. CHILAYA and K. G. JAPARIDZE \\ Institute of Cybernetics Academy of Sciences of Georgian \\ SSR, Tbilisi 380086, S. Euli str. 5, USSR
}

\begin{abstract}
Résumé. - On a étudié la dépendance en température et en concentration de la viscosité de mélanges de cristaux liquides nématiques et de corps non mésomorphes optiquement actifs : les L-menthylchloracetate, 1-menthylbenzoate et l-menthyloxalate. On a montré que l'augmentation de la viscosité pour de faibles concentrations d'additifs $\left(C_{\mathrm{m}}<3 \%\right)$ est due à la variation de la structure (formation de la phase cholestérique), tandis que l'influence de facteurs géométriques spécifiques aux molécules d'additif se manifeste à des concentrations élevées. Le temps de montée et le seuil de tension de l'instabilité électro-hydrodynamique ont été déterminés. L'augmentation de la viscosité entraîne un accroissement du temps de montée et les seuils de tension croissent lorsque le pas de l'hélice décroît.

Abstract. - We have measured the viscosity in mixtures of nematics and optically active non mesomorphic compounds both as a function of temperature and concentration. L-menthylchloracetate, 1 -menthylbenzoate and 1-menthyloxalate have been used as additives. We show that the increase of the viscosity at low additive concentration $\left(C_{\mathrm{m}}<3 \%\right)$ is due to a general structure change (formation of a cholesteric phase), whereas the specific geometry of the molecules has a remarked influence at higher concentrations. The time of onset and the voltage threshold for electrohydrodynamic instabilities have also been determined. The rise in viscosity is accompanied by a corresponding rise in onset time and the voltage threshold increases with increased helicity.
\end{abstract}

In recent years interest has grown in application of nematic-chiral liquid crystal (LC) mixtures in visualization and display systems. In contrast to cholesterol esters they have some advantages : electrochemical stability and capacity of varying the spiral pitch (P) in a wide range, a great choice of nematic liquid crystals (NLC) as well as of optically active additives (OAA). To date a number of NLC satisfying technical requirements have been synthesized. However OAA change the physical characteristics of NLC. The present papers deals with a study of the pecularities of these changes. The temperature and concentration dependencies of viscosity $(\eta)$, the rise time $\left(\tau_{\mathrm{r}}\right)$, and threshold voltage $\left(U_{\mathrm{th}}\right)$ of the electrohydrodynamic instability (EHDI) of NLC mixtures with nonmesomorphic OAA are investigated.

1. Materials and experimental techniques. - A mixture of azoxycompounds was taken as the nematic material : p-n-butyl-p'-methoxyazoxybenzene and p-n-butyl-p'-heptanoylazoxybenzene in the ratio $2: 1$. This NLC mixture has a negative dielectric anisotropy and nematic range $-10-+74{ }^{\circ} \mathrm{C}$. The optically active nonmesomorphic compounds : L-menthylcholoracetate (I), L-menthylbenzoate (II) and Lmenthyloxalate (III) were added to NLC.
The viscosity was measured by an Ostwald viscometer with diameter of the capillary $1 \mathrm{~mm}$.

Electrooptic characteristics were measured in a sandwich-type cell of $d=40 \mu \mathrm{m}$ thickness. The initial planar alignment of the LC was attained by unidirectional rubbing of the electrode surfaces. Single electrical pulses (or pulses with a long duty between them) of 0.1-1 s dulation were applied to the cells. The EHDI threshold was recorded on the appearance of a diffraction pattern on the passage of laser beam through substance layer.

2. Results and discussion. -2.1 Viscosity. - The dependence $\eta$ on the molar concentration $\left(C_{\mathrm{M}}\right)$ of $\mathrm{OAA}$ at the temperature $20^{\circ} \mathrm{C}$ is shown in figure 1. At this temperature for NLC $\eta=0.29$ poise. By adding OAA the value $\eta$ increases from the initial 0.29 poise to 0.37 poise (for NLC + I), 0.41 poise (for NLC + II) and 0.58 poise (for NLC + III) at concentration $C_{\mathrm{M}} \sim 3 \%$ for all cases. This sharp increase of $\eta$ at small $C_{\mathrm{M}}$ is apparently due to the formation of spiral structure. The difference in the value $\eta$ of mixtures in this range $\left(C_{\mathrm{M}}<3 \%\right)$ correlates with the spiral induction power $(A)$ of OAA. The value $A$ was determined by the formula $1 / P=A C_{\mathrm{M}}$ ( $P$-pitch in $\mu \mathrm{m}, C_{\mathrm{M}}$-molar concentration of OAA), 


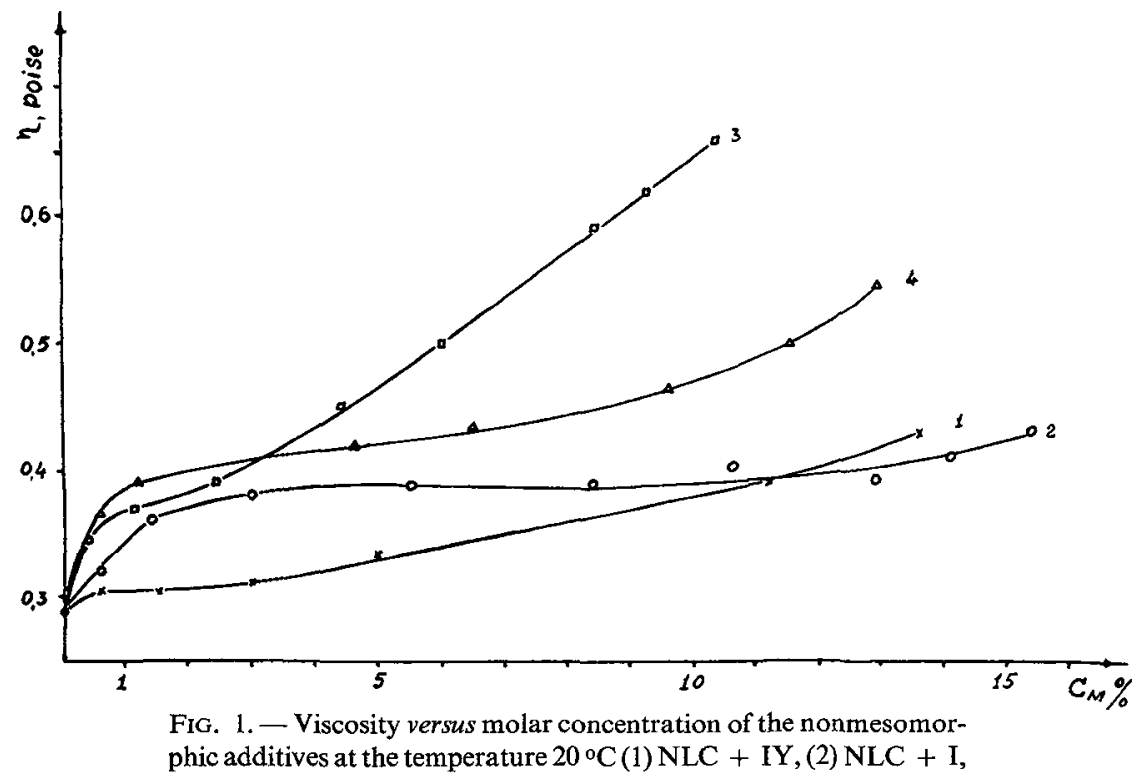

(3) NLC + III, (4) NLC + II.

and it respectively amounts to : for I $-A=0.037$, II $-A=0.095$, III $-A=0.036$ [1]. $\mathrm{P}$ was determined at a temperature $2^{\circ}$ lower than the cholestericisotropic transition temperature for each composition. It should be noted that while using of I and II as OAA the pitch of mixtures did not change with temperature $(\mathrm{d} P / \mathrm{d} t=0)$, whereas in mixtures with III a decrease of pitch was observed with a decrease of temperature $(\mathrm{d} P / \mathrm{d} t>0)$.

At higher concentrations of OAA $\left(C_{\mathrm{M}}>3 \%\right)$ along with influence of spiral structure, the stereochemistry effect of the molecules of optically active substances becomes apparent, leading to a drastic increase of $\eta$ at the use of III, the molecule of which contains two menthol rings.

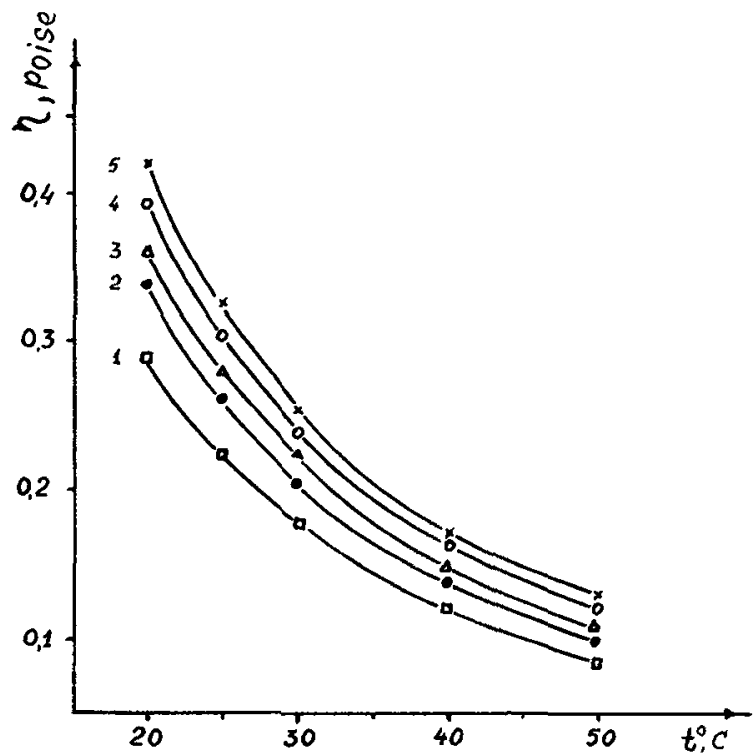

FIG. 2. - Temperature dependence of the viscosity for NLC and various mixtures (1) NLC, (2) $95 \% \mathrm{NLC}+5 \%$ IY, (3) $97 \%$ $\mathrm{NLC}+3 \%$ I, (4) $97.6 \% \mathrm{NLC}+2.4 \%$ III, (5) $95.4 \%$ $\mathrm{NLC}+4.6 \% \mathrm{II}$.
In order to eliminate the effect of spiral structure formation on optically nonactive substance-cyclohexyloxalate (IV), which has a similar structure with III, was used as the addition. In this case, as shown in figure 1 , at small concentrations of IV a sharp increase of $\eta$ is no longer observed.

The temperature dependence law of mixtures has an exponential character, agreeing with the published data for pure nematic [2]. In figure 2 these data have been plotted for some mixtures.

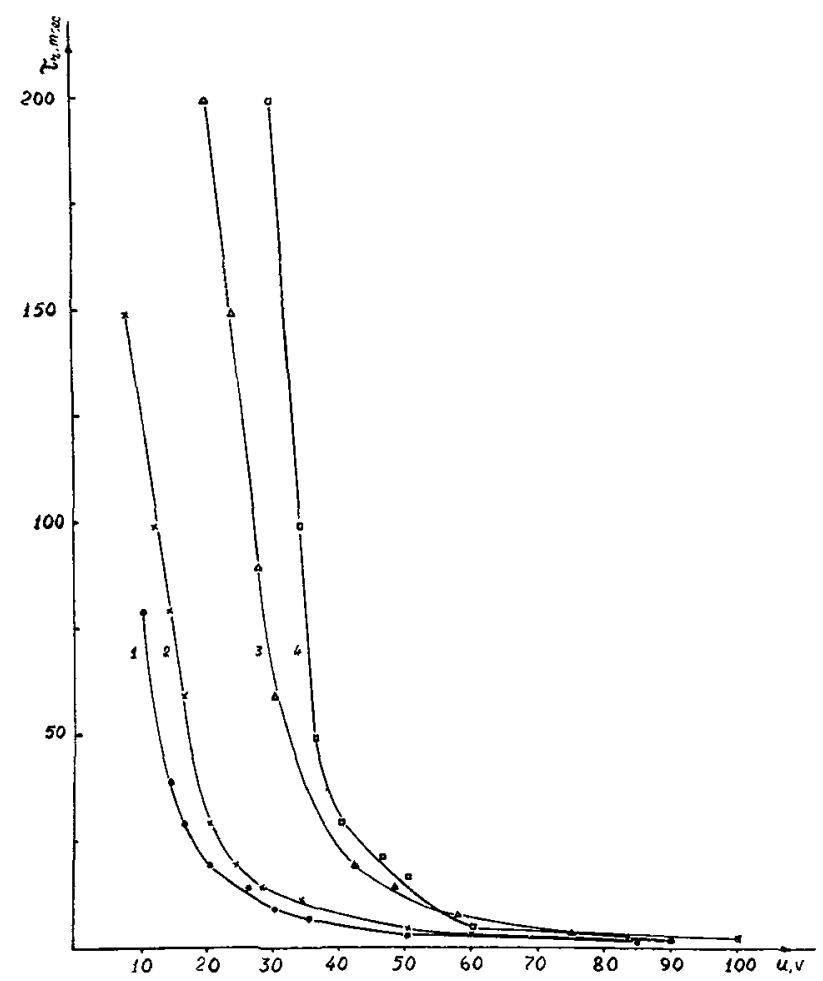

FIG. 3. - Voltage dependence of the rise time for NLC and various mixtures at the $t=20{ }^{\circ} \mathrm{C}$ (1) NLC, (2) $97.5 \% \mathrm{NLC}+2.5 \% \mathrm{I}$, (3) $93.3 \% \mathrm{NLC}+6.7 \%$ III, (4) $96.3 \% \mathrm{NLC}+3.7 \%$ II. 
2.2 ElectroOPtIC CHARACTERISTICS. - Figure 3 shows the dependence $\tau_{\mathrm{r}}$ on the electrical voltage $U$ applied to LC for various mixtures at temperature $20^{\circ} \mathrm{C}$. As seen from figure 3 in cases $U>50 \mathrm{~V}$ the values of $\tau_{\mathrm{r}}$ are close (for all mixturer). In order to study the influence of additives on $\tau_{\mathrm{r}}$ the values are taken for $U=20 \mathrm{~V}$ (for the case), when the effect of the electric field is small. Values of $\tau_{\mathrm{r}}$ for a different mixtures are given in table. The rise time increases with the increase of $\eta$.

In figure 4 dependence $U_{\text {th }}$ on the temperature are shown. Comparing different mixtures, as shown in figure $4, U_{\text {th }}$ increases with the decrease of $P$. This also occurs for the temperature dependence of $U_{\text {th }}$ of mixtures with III, because, as noted in the foregoing in these mixtures $\mathrm{d} P / \mathrm{d} t>0$. For mixtures with $\mathrm{I}$ and II $U_{\text {th }}$ does not change sharply. $C_{\mathrm{M}}=4.6 \%$ with II is an exception. The reason for this dependence is not clear. The linear dependence of $U_{\mathrm{th}}$ on the concentration of cholesteryl oleate, observed in [3] is apparently connected with the decrease of $P$, rather than with increase viscosity, as suggested by authors.

Of the investigated mixtures the highest values of $\tau_{\mathrm{r}}$ and $U_{\mathrm{th}}$ was observed for III $C_{\mathrm{M}}=6 \%$, having maximum value of viscosity and minimum value of pitch. The best times $\tau_{\mathrm{r}}$ and low $U_{\mathrm{th}}$ (similar to $U_{\mathrm{th}}$ of NLC) is noted for I $C_{\mathrm{M}}=3.4 \%$, having the minimum value of viscosity and maximum value of pitch.

If IY is used as the additive, the value $U_{\mathrm{th}}$ remains unchanged $\left(\sim 6 \mathrm{~V}\right.$ at $\left.20^{\circ} \mathrm{C}\right)$, whereas $\tau_{\mathrm{r}}$ increases slightly. At $20^{\circ} \mathrm{C} \tau_{\mathrm{r}}$ changes from $20 \mathrm{~ms}$ (for NLC) to $30 \mathrm{~ms}$ (for the mixture with IY $C_{\mathrm{M}}=6.2 \%$ ).

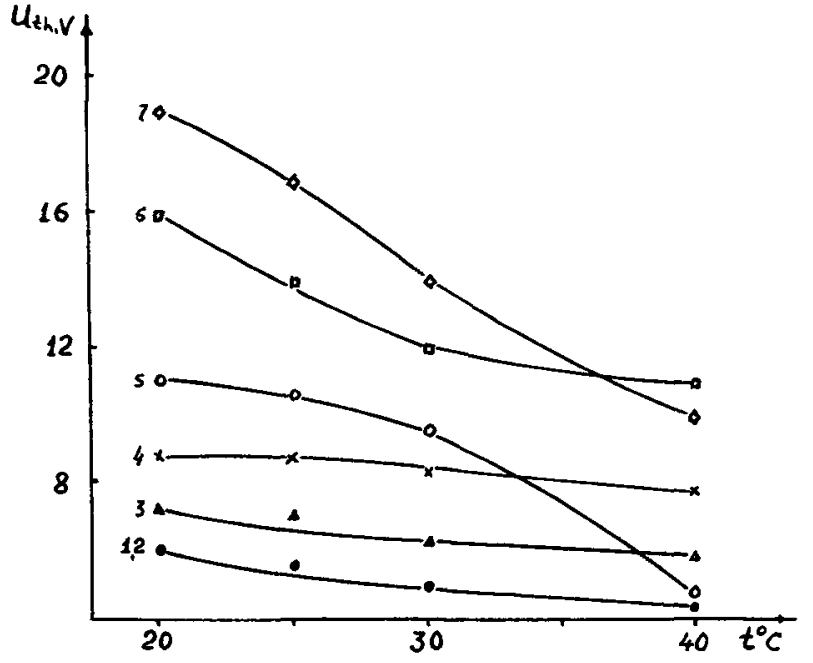

FIG. 4. - Threshold voltage versus the temperature (1) NLC, (2) $96.6 \% \mathrm{NLC}+3.4 \% \mathrm{I}, \mathrm{P}=8,5 \mu \mathrm{m}$, (3) $99 \% \mathrm{NLC}+1 \% \mathrm{II}$, $P-6.6 \mu \mathrm{m}$, (4) $91.6 \% \mathrm{NLC}+8.4 \% \mathrm{I}, P=3 \mu \mathrm{m},(5) 97.6 \%$ $\mathrm{NLC}+2.4 \% \mathrm{III}, P=5.4 \mu \mathrm{m}$ at $20{ }^{\circ} \mathrm{C}, P=6 \mu \mathrm{m}$ at $25{ }^{\circ} \mathrm{C}$, $P=6.4 \mu \mathrm{m}$ at $30^{\circ} \mathrm{C}, P=7.4 \mu \mathrm{m}$ at $40{ }^{\circ} \mathrm{C},(6) 95.4 \% \mathrm{NLC}+4.6 \%$ II, $P=2.1 \mu \mathrm{m}$, (7) $94 \% \mathrm{NLC}+6 \%$ III, $P=1.7 \mu \mathrm{m}$ at $20{ }^{\circ} \mathrm{C}$, $P=1.8 \mu \mathrm{m}$ at $25^{\circ} \mathrm{C}, P=1.9 \mu \mathrm{m}$ at $30^{\circ} \mathrm{C}, P=2.2 \mu \mathrm{m}$ at $40^{\circ} \mathrm{C}$.

3. Conclusions. - Additions of optically active substances to NLC leads to an increase of viscosity due to both structural change (formation of cholesteric structure) and the influence of the geometric factors of additives. The increase of viscosity causes on increase of rise time. Threshold voltage of EHDI increases with the decrease of pitch.

\begin{tabular}{|c|c|c|c|c|c|c|c|c|c|}
\hline \multirow[b]{2}{*}{ Mixtures } & \multirow[b]{2}{*}{$C_{\mathrm{M}}$} & \multicolumn{4}{|c|}{$\eta$ poise } & \multicolumn{4}{|c|}{$\tau_{\mathrm{r}} \mathrm{ms}$} \\
\hline & & $20^{\circ} \mathrm{C}$ & $25^{\circ} \mathrm{C}$ & $30^{\circ} \mathrm{C}$ & $40^{\circ} \mathrm{C}$ & $20^{\circ} \mathrm{C}$ & $25^{\circ} \mathrm{C}$ & $30^{\circ} \mathrm{C}$ & $40^{\circ} \mathrm{C}$ \\
\hline - & - & 一 & - & - & - & - & - & - & - \\
\hline NLC & - & 0.29 & 0.23 & 0.18 & 0.12 & 20 & 18 & 15 & 10 \\
\hline \multirow{2}{*}{$\mathrm{NLC}+\mathrm{I}$} & 3.4 & 0.36 & 0.28 & 0.23 & 0.16 & 33 & 24 & 21 & 19 \\
\hline & 8.4 & 0.38 & 0.29 & 0.24 & 0.17 & 49 & 44 & 41 & 17 \\
\hline \multirow{2}{*}{$\mathrm{NLC}+\mathrm{II}$} & 1.2 & 0.39 & 0.30 & 0.24 & 0.16 & 40 & 30 & 20 & 17 \\
\hline & 4.6 & 0.42 & 0.33 & 0.25 & 0.17 & 200 & 90 & 80 & 62 \\
\hline \multirow{2}{*}{$\mathrm{NLC}+\mathrm{III}$} & 2.4 & 0.40 & 0.30 & 0.24 & 0.16 & 60 & 43 & 34 & 12 \\
\hline & 6.0 & 0.50 & 0.38 & 0.30 & 0.22 & 800 & 700 & 600 & 150 \\
\hline \multirow{2}{*}{$\mathrm{NLC}+\mathrm{IV}$} & 0.6 & 0.30 & 0.25 & 0.19 & 0.13 & 25 & 19 & 12 & 8 \\
\hline & 5.4 & 0.33 & 0.27 & 0.21 & 0.14 & 27 & 15 & 14 & 12 \\
\hline
\end{tabular}

References

[1] Elashvili, Z. M., Piliashyili, T. S., Chilaya, G. S., JapaRiDZE, K. G., Abstracts of the Second Liquid Crystal conference of socialist countries, Sunny Beach F-2 251 1977.
[2] Kerllenevich, B., Coche, A., Mol. Cryst. Liq. Cryst. 24 (1973) 113.

[3] Meyerhofer, D., Pasierb, E. F., Mol. Cryst. Liq. Cryst. 20 (1973) 279. 